\title{
Long-term results after concomitant cardiac surgery and pulmonary resection
}

\author{
Alexander Kogan ${ }^{1}$, Merav Rocah², Sergey Preisman ${ }^{3}$, Jacob Lavee${ }^{1}$, David Simansky², Alon Ben Nun², \\ Ehud Raanani ${ }^{1}$, Leonid Sternik ${ }^{1}$ \\ ${ }^{1}$ Department of Cardiac Surgery, Sheba Medical Center, Tel Hashomer, affiliated with the Sackler School of \\ Medicine, Tel Aviv University, Tel Aviv, Israel \\ ${ }^{2}$ Department of Thoracic Surgery, Sheba Medical Center, Tel Hashomer, affiliated with the Sackler School of Medicine, Tel Aviv \\ University, Tel Aviv, Israel \\ ${ }^{3}$ Department of Anesthesiology, Sheba Medical Center, Tel Hashomer, affiliated with the Sackler School of Medicine, Tel Aviv \\ University, Tel Aviv, Israel
}

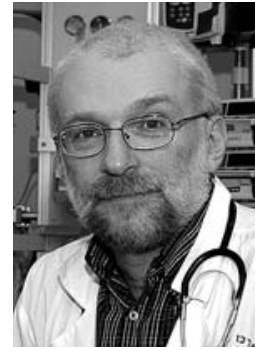

Kardiochirurgia i Torakochirurgia Polska 2013; 10 (4): 347-351

\begin{abstract}
Background: Concomitant lesions of the heart and lung are uncommon, but when present they pose a challenge for cardiac and thoracic surgeons. Patients with lung cancer and heart disease are at a high risk for postoperative death or severe cardiovascular complications.

Aim of the study: To report our results of concomitant cardiac surgery and lung resection.

Material and methods: From 1994 to 2012, 18 patients with cardiac disorders and lung cancer or another lung disease were operated on. Twelve patients underwent coronary artery bypass grafting, 3 patients underwent aortic valve replacement and 3 patients underwent another cardiac surgery procedure. The pulmonary resections consisted of pneumonectomy in 1 patient, lobectomy in 6 patients and wedge excision in 10 patients. Follow-up was obtained for all 18 patients (mean follow-up 70.6 months; range 224 to 0.7 months).

Results: The pathologic examination confirmed lung malignancy in 12 patients. Five patients were operated on due to a non-oncologic pathology and 1 patient underwent lung volume resection. Overall late survival was $88 \%$ and $67 \%$ at 1 and 5 years, respectively.

Conclusions: Lung resection carried out concomitantly with cardiac surgery is safe and effective. A combined procedure avoids the need for a second major thoracic procedure and may improve clinical outcome.
\end{abstract}

Key words: cardiac surgery; thoracic surgery; concomitant surgery.

\section{Streszczenie}

Wprowadzenie: Jednoczasowe zmiany chorobowe serca i płuc nie są częste, jednakże ich występowanie stanowi wyzwanie dla kardio- i torakochirurgów. Pacjenci z rakiem płuca i chorobą serca narażeni są w wysokim stopniu na pooperacyjną śmierć lub poważne powikłania sercowo-naczyniowe.

Cel: Celem pracy było przedstawienie uzyskanych przez autorów wyników stosowania jednoczasowych operacji kardiochirurgicznych i resekcji płucnych.

Materiał i metody: Od 1994 do 2012 roku 18 pacjentów z zaburzeniami sercowymi i rakiem płuc lub innymi chorobami płuc zostało poddanych operacji. 12 pacjentów przeszło pomostowanie aortalno-wieńcowe, 3 pacjentów przeszło wymianę zastawki aortalnej, a 3 pacjentów - inne zabiegi kardiochirurgiczne. Wykonano następujące resekcje płucne: pneumonektomię u 1 pacjenta, lobektomię u 6 pacjentów oraz resekcję klinową u 10 pacjentów. Zebrano dane dotyczące obserwacji wszystkich pacjentów (średni czas obserwacji: 70,6 miesięcy; zakres od 224 do 0,7 miesięcy).

Wyniki: Badanie patologiczne potwierdziło obecność złośliwych zmian płucnych u 12 pacjentów. Pięcioro pacjentów było operowanych ze względu na patologie nieonkologiczne, a u jednego pacjenta wykonano operacyjne zmniejszenie objętości płuc. Całkowite późne przeżycia wyniosły 88\% i 67\% odpowiednio dla przeżyć jednorocznych i 5-letnich.

Wnioski: Wykonywanie operacji płucnych jednoczasowo z zabiegami kardiochirurgicznymi jest bezpieczne i skuteczne. Połączenie dwóch zabiegów pozwala na uniknięcie konieczności przeprowadzenia kolejnego poważnego zabiegu torakochirurgicznego i może owocować lepszymi wynikami klinicznymi.

Stowa kluczowe: kardiochirurgia, torakochirurgia, jednoczasowe zabiegi chirurgiczne.

Address for correspondence: Alexander Kogan, MD, Department of Cardiac Surgery, Sheba Medical Center, Tel Hashomer 52621, Israel, tel. +972-52-6668270, fax +972-3-5302410, e-mail: alexanderkogan140@hotmail.com, Alexander.Kogan@sheba.health.gov.il 


\section{Introduction}

Concomitant lesions of the heart and lung are uncommon [1], but when present they pose a challenge for cardiac and thoracic surgeons. Patients with lung cancer and heart disease are at high risk of postoperative death or severe cardiovascular complications. The optimal treatment for these patients is unclear and controversial. In 1978 Dalton [2] reported the first experience with a one-stage cardiac operation and lung resection. Several studies have found that either a combined or staged procedure is effective [3]. Regarding safety, cost, hospital stay, and delay in tumor management, each technique has its own benefits and drawbacks in treating these high-risk patients.

\section{Aim of the study}

The aim of this study was to review the early and longterm results of concomitant lung resection for cancer and other pulmonary diseases with simultaneous cardiac surgery.

\section{Material and methods}

This was a retrospective, observational study, which included prospectively collected data from consecutive patients who had undergone concomitant cardiac surgery and lung resection at a large tertiary university hospital during the 18 years between 1994 and 2012. The data collection forms were entered into a computerized department database, and the Ethics Committee of our Medical Center approved the use of our database as a source of information. In this period, 18 patients (14 men and 4 women, aged 49 to 85 years, mean age 69.6 years) with lung cancer or another lung disease and coronary disease and/or valve disorders were operated on.

All cardiac procedures were performed on cardiopulmonary bypass (CPB). Before initializing CPB, systemic heparinization was accomplished with a heparin dose of $400 \mathrm{U} / \mathrm{kg}$. Additional heparin was administered during CPB to maintain an activated coagulation time of $>480$ seconds. The mean arterial pressure was maintained between 60 and $80 \mathrm{~mm} \mathrm{Hg}$ using boluses of phenylephrine as required. Serum glucose levels were controlled with intermittent administration of insulin. Hematocrit was maintained at $22 \%$ with the administration of packed red blood cells as necessary. Cardiac arrest was achieved by antegrade and/or retrograde blood cardioplegia. Topical cooling was not used, and core temperature was between $33^{\circ}$ and $35^{\circ} \mathrm{C}$. Prior to discontinuation of CPB patients were warmed to $37^{\circ} \mathrm{C}$. Lung resection was performed immediately after completion of the cardiac procedure and after reversal of heparin. The approach to the heart and lung were through a median sternotomy.

\section{Results}

Twelve patients underwent coronary artery bypass grafting, 3 patients underwent aortic valve replacement, 2 patients underwent combined valve replacement and coronary artery bypass grafting, and 1 patient underwent aortic surgery. In all operations the cardiac procedure on extracorporeal circulation was followed by lung resection after reversing heparin. The pulmonary resections consisted of pneumonectomy in 1 patient, lobectomy in 6 patients, and a wedge excision in 11 patients. One patient underwent a completion lobectomy 3 weeks after the concomitant procedure [coronary artery bypass graft (CABG) + wedge resection]. Three patients with N2 disease received adjuvant chemotherapy.

Pathologic examination confirmed lung malignancy in 12 patients, adenocarcinoma $(n=7)$, squamous cell carcinoma $(n=3)$ and carcinoid $(n=2)$. Five patients were operated on for a non-oncologic pathology and 1 patient underwent lung volume reduction surgery (Table I).

One patient died 20 days after pneumonectomy due to multisystem organ failure. No patient needed re-exploration because of bleeding. Five patients (29\%) developed atrial fibrillation in the early postoperative period. Mean ventilator support was $14.6 \pm 32.4$ hours (range 4 to 480 hours) and mean ICU stay was $26.6 \pm 26.6$ hours (range 14 to 480 hours). Mean hospital stay was $6.6 \pm 2.6$ days (range 5 to 22 days).

Follow-up was obtained on all 18 patients. For the whole group of patients mean follow-up was $70.6 \pm 61.4$ months (range 224 to 0.7 months) and the survival rate was $88 \%$ and $47 \%$ at 1 and 5 years, respectively. In the group of 12 patients with malignant lung disease mean follow-up was $56.2 \pm 43.8$ months (range 120 to 0.7 months) and the survival rate was $92 \%$ and $42 \%$ at 1 and 5 years, respectively (Fig. 1). Three patients died because of recurrence of malignant disease, 1 after lobectomy and 2 after wedge resection.

\section{Discussion}

Concomitant operations are surgical procedures performed simultaneously on two or more sites for different unrelated diseases. The main purpose of these operations is to free the patient from several diseases simultaneously and to achieve a long-lasting remission or cure. Advances in surgical techniques, resuscitation and anesthesiology support over the years have allowed concomitant cardiac operations and lung resections to be performed for simultaneous heart and pulmonary disease. Danton and coworkers [4] presented their own results and reviewed 290 patients

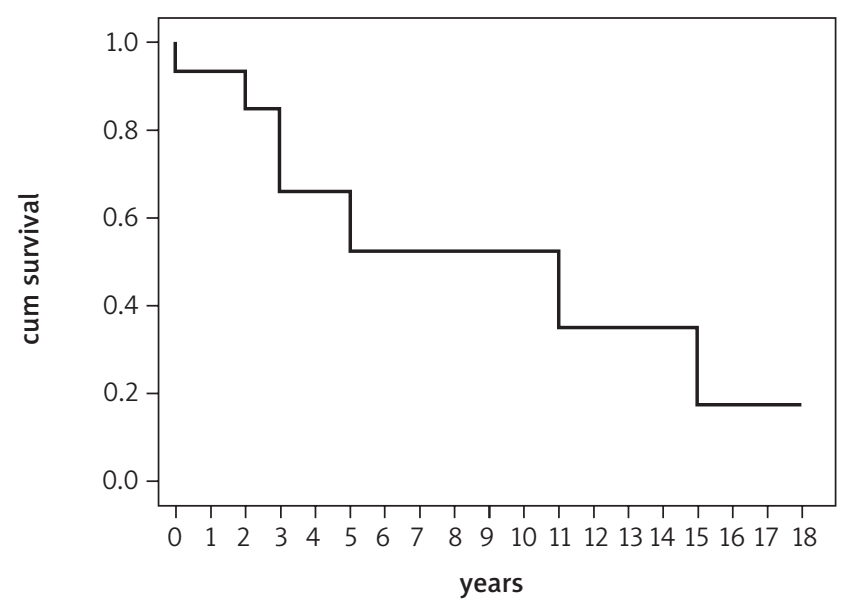

Fig. 1. Survival of patients after concomitant cardiac surgery and pulmonary resection 
Tab. I. Demographic and perioperative data

\begin{tabular}{|c|c|c|c|c|c|c|c|c|}
\hline $\begin{array}{l}\text { No. of } \\
\text { patient }\end{array}$ & Sex & Age & Cardiac pathology & Lung pathology & $\begin{array}{l}\text { Lung cancer } \\
\text { stage }\end{array}$ & $\begin{array}{l}\text { Cardiac } \\
\text { surgery }\end{array}$ & Lung surgery & $\begin{array}{l}\text { Follow-up } \\
\text { (mo) }\end{array}$ \\
\hline 1 & M & 64 & IHD, triple-vessel disease & squamous cell carcinoma & T2N2 (IIIA) & CABG & left upper lobectomy & 18 \\
\hline 2 & M & 85 & IHD, triple-vessel disease & adenocarcinoma & T2NO (IB) & CABG & left upper lobectomy & 120 \\
\hline 3 & M & 76 & IHD, triple-vessel disease & squamous cell carcinoma & T2N1 (IIA) & CABG & left lower lobectomy & 105 \\
\hline 4 & M & 72 & IHD, triple-vessel disease & squamous cell carcinoma & T2N2 (IIIA) & CABG & right upper lobectomy & 98 \\
\hline 5 & $M$ & 76 & $\begin{array}{l}\text { IHD, severe left main } \\
\text { stenosis }\end{array}$ & adenocarcinoma & $\mathrm{T} 1 \mathrm{~N} x(\mathrm{IA})$ & CABG & $\begin{array}{c}\text { wedge excision right } \\
\text { upper lobe }\end{array}$ & 120 \\
\hline 6 & $M$ & 56 & IHD, triple-vessel disease & adenocarcinoma & T1N0 (IA) & CABG & left upper lobectomy & 60 \\
\hline 7 & $M$ & 76 & $\begin{array}{l}\text { IHD + severe mitral } \\
\text { insufficiency }\end{array}$ & carcinoid & T2N1 (IIA) & $\begin{array}{l}\text { MVR + } \\
\text { CABG }\end{array}$ & left pneumonectomy & 0.6 \\
\hline 8 & $\mathrm{~F}$ & 84 & severe aortic stenosis & adenocarcinoma & $\mathrm{T} 1 \mathrm{~N} \times(\mathrm{IA})$ & AVR & $\begin{array}{c}\text { wedge excision left } \\
\text { lower lobe }\end{array}$ & 54 \\
\hline 9 & M & 71 & $\begin{array}{l}\text { IHD, severe left main } \\
\text { stenosis }\end{array}$ & adenocarcinoma & T2NO (IB) & CABG & $\begin{array}{c}\text { wedge excision left } \\
\text { lower lobe }\end{array}$ & 36 \\
\hline 10 & M & 83 & severe aortic stenosis & carcinoid & $\mathrm{T} 1 \mathrm{~N} \times(\mathrm{IA})$ & AVR & $\begin{array}{c}\text { wedge excision right } \\
\text { lower lobe }\end{array}$ & 32 \\
\hline 11 & $\mathrm{~F}$ & 63 & $\begin{array}{l}\text { IHD, two-vessel disease, } \\
\text { severe aortic stenosis }\end{array}$ & adenocarcinoma & $\mathrm{T} 1 \mathrm{Nx}(\mathrm{IA})$ & $\begin{array}{l}\mathrm{AVR}+ \\
\mathrm{CABG}\end{array}$ & $\begin{array}{c}\text { wedge excision left } \\
\text { upper lobe }\end{array}$ & 16 \\
\hline 12 & $\mathrm{~F}$ & 75 & $\begin{array}{l}\text { ascending aortic aneu- } \\
\text { rism }\end{array}$ & adenocarcinoma & T1N3 (IIIA) & $\begin{array}{c}\text { aortic } \\
\text { surgery }\end{array}$ & $\begin{array}{c}\text { wedge excision right } \\
\text { upper lobe }\end{array}$ & 15 \\
\hline 13 & $\mathrm{~F}$ & 67 & IHD, Triple-vessel disease & granuloma & & CABG & $\begin{array}{c}\text { wedge excision left } \\
\text { upper lobe }\end{array}$ & 224 \\
\hline 14 & M & 69 & $\begin{array}{l}\text { IHD, severe left main } \\
\text { stenosis }\end{array}$ & hamartoma & & CABG & $\begin{array}{c}\text { wedge excision left } \\
\text { upper lobe }\end{array}$ & 167 \\
\hline 15 & M & 49 & IHD, triple-vessel disease & hamartoma & & CABG & $\begin{array}{l}\text { wedge excision left } \\
\text { upper lobe }\end{array}$ & 67 \\
\hline 16 & M & 56 & $\begin{array}{c}\text { IHD, severe left main } \\
\text { stenosis }\end{array}$ & granuloma & & CABG & $\begin{array}{l}\text { wedge excision left } \\
\text { lower lobe }\end{array}$ & 56 \\
\hline 17 & $\mathrm{~F}$ & 61 & severe aortic stenosis & bullous emphysema & & AVR & left upper lobectomy & 11 \\
\hline 18 & M & 68 & IHD, triple-vessel disease & hamartoma & & CABG & $\begin{array}{c}\text { wedge resection left } \\
\text { upper lobe }\end{array}$ & 11 \\
\hline
\end{tabular}

IHD - ischemic heart disease; CABG - coronary artery bypass graft; $M V R$ - mitral valve repair; AVR - aortic valve replacement

who were operated on in the years 1965-1997. Their study showed an immediate postoperative mortality between 0 and $6.7 \%$, and 5 -year survival for oncologic patients between $35 \%$ and $80 \%$. More recently a number of nonrandomized studies [5, 6-15] have been published. In these studies (Table II) the results of 161 patients operated on in the years 1990-2011 were examined. Perioperative mortality and oncologic 5-year survival practically did not change, remaining at the level $0-6 \%$ and $9-86 \%$ respectively. As in our study, most operations [3, 10-16] were performed in one stage with the cardiac procedure followed by lung resection. Voets et al. [3] compared one-stage versus two-stage procedures and concluded that there was no difference between the two groups regarding mortality; however, greater perioperative risk makes concomitant procedures less attractive.

Ciriaco et al. [5] and Ambrogi et al. [6] reported 17 patients who had a two-stage procedure. Lung surgery was performed with a mean interval of 5 weeks after cardiac surgery. Ciriaco et al. [5] compared two-stage surgical revascularization with two-stage percutaneous coronary intervention $(\mathrm{PCl})$ and pulmonary resection. There was no reported difference between the groups regarding mortali- ty or complication rate. The problem after $\mathrm{PCl}$ is the need to receive long-term aspirin and IIb/IIla inhibitors which can cause excessive bleeding, during an invasive procedure or cardiovascular events in case of cessation. Albaladejo et al. [17] reported that patients after $\mathrm{PCl}$ undergoing operations are at high risk of major bleeding (9.5\%) or perioperative myocardial infarction including stent thrombosis $(10.6 \%)$ irrespective of the stent type.

In patients with a recently implanted drug-eluting stent and high risk for stent thrombosis (e.g. within the first weeks after implantation) needing surgery, a 'bridging strategy' using tirofiban or eptifibatide may allow temporary withdrawal of oral clopidogrel without increasing the risk of bleeding [7, 8]. Guidelines on Myocardial Revascularization [9] also advocated this approach and do not recommend using low-molecular weight heparin.

Voets et al. [3] and Hosoba et al. [16] reported that a number of patients underwent a lung resection through a separate thoracotomy after the sternum was closed. Dyszkiewicz et al. [10, 14] and Saxena et al. [11] advocate concomitant one-stage off-pump coronary revascularization and lung resection. However, Schoenmakers et al. 
Tab. II. Concomitant cardiac operation and lung resection: review of literature

\begin{tabular}{|c|c|c|c|c|c|c|}
\hline Author, year & Study date & $\begin{array}{c}\text { Total } \\
\text { patients }\end{array}$ & $\begin{array}{l}\text { Oncological } \\
\text { patients }\end{array}$ & Follow-up (mo) & Oncological survival & $\begin{array}{l}\text { Non-oncological } \\
\text { survival }\end{array}$ \\
\hline Ciriaco et al. 2002 [5] & $1993-2001$ & 6 & $6(100 \%)$ & NA & NA & \\
\hline Ambrogi et al. 2003 [6] & 1990-1997 & 11 & $11(100 \%)$ & 1-76 (range) & $36 \%-1$-year $9 \%-5$-year & \\
\hline Dyszkiewicz et al. 2004 [10] & $1999-2002$ & 13 & $13(100 \%)$ & $\begin{array}{l}\text { 7-36 (range) } \\
22 \text { (median) }\end{array}$ & NA & \\
\hline Saxena et al. 2004 [11] & $2000-2003$ & 6 & $5(83 \%)$ & 9-36 (range) & NA & \\
\hline Shoenmakers et al. 2007 [12] & $1994-2005$ & 43 & $43(100 \%)$ & 56 (median) & $58 \%-2$-year, 35\%-5-year & \\
\hline Prokakis et al. 2008 [13] & $2004-2006$ & 5 & $5(100 \%)$ & 6-30 (range) & NA & \\
\hline Dyszkiewicz et al. 2008 [14] & $2001-2006$ & 25 & $25(100 \%)$ & 8-60 (range) & $50 \%$ estimated 3-year & \\
\hline Cathenis et al. 2009 [15] & $2000-2008$ & 27 & $27(100 \%)$ & 30.7 (median) & & \\
\hline Hosoba et al. 2012 [16] & $2008-2011$ & 11 & $11(100 \%)$ & $\begin{array}{c}19 \pm 11 \text { (mean) } \\
2-34 \text { (range) }\end{array}$ & $80 \%$ estimated 2 -year & \\
\hline Zhang et al. 2012 [18] & $2004-2011$ & 33 & $14(42 \%)$ & & $44 \%-5$-year & $86 \%-5$-year \\
\hline Kogan et al. 2012 & 1994-2011 & 18 & $12(71 \%)$ & $\begin{array}{l}70 \pm 61 \text { (mean) } \\
0.7-220 \text { (range) }\end{array}$ & $88 \%$ - 1-year $42 \%-5$-year & $\begin{array}{l}80 \%-1 \text {-year } \\
60 \% \text {-5-year }\end{array}$ \\
\hline
\end{tabular}

[12] found no significant difference in using an on-pump or off-pump technique to perform combined cardiac and lung surgery in relation to postoperative complications and hospital survival. In our series the decision to perform the operation off- or on-pump was made by the operating surgeon, but all isolated coronary artery bypass grafting (CABG) was performed on-pump, and it is not possible to compare the results, although off-pump technique may have advantages in this group of patients.

Zhang et al. [18] reported 86\% 5-year survival in patients after concomitant resection of benign lung tumors, compared to $60 \%$ in our patients. One patient underwent AVR and lung volume reduction. Schmid et al. [19] reported $22 \%$ early postoperative mortality after concomitant cardiac surgery and lung volume reduction.

There are two main limitations of this study. First, we present observation retrospective analysis rather than a randomized control trial. This heterogeneous group of patients includes a mixture of pathologies such as coronary disease (13), valvular heart disease (5), aortic disease (1), lung cancer of different types (12), hamartoma (3), granuloma (2) and emphysema (1), and therefore our results must be interpreted with caution. Second, the difficulty with longitudinal studies such as ours is that overall mortality has been decreasing over time.

\section{Conclusions}

Lung resection carried out concomitantly with cardiac surgery is safe and effective. A combined one-stage procedure avoids the need for a second major thoracic procedure and may improve clinical outcome.

\section{References}

1. Johnson JA, Landreneau RJ, Boley TM, Haggerty SP, Hattler B, Curtis JJ, Hazelrigg SR. Should pulmonary lesions be resected the time of open heart surgery? Am Surg 1996; 62: 300-303.
2. Dalton ML Jr, Parker TM, Mistrot JJ, Bricker DL. Concomitant coronary artery bypass and major noncardiac surgery. J Thorac Cardiovasc Surg 1978; 75: 621-624.

3. Voets AJ, Joesoef KS, van Teeffelen ME. Synchroneously occurring lung cancer (stages I-II) and coronary artery disease: concomitant versus staged surgical approach. Eur J Cardiothorac Surg 1997; 12: 713-717.

4. Danton MH, Anikin VA, McManus KG, McGuigan JA, Campalani G. Simultaneous cardiac surgery with pulmonary resection: presentation of series and review of literature. Eur J Cardiothorac Surg 1998; 13: 667-672.

5. Ciriaco P, Carretta A, Calori G, Mazzone P, Zannini P. Lung resection for cancer in patients with coronary arterial disease: analysis of short-term results. Eur J Cardiothorac Surg 2002; 22: 35-40.

6. Ambrogi V, Pompeo E, Elia S, Pistolese GR, Mineo TC. The impact of cardiovascular comorbidity on the outcome of surgery for stage I and II nonsmall-cell lung cancer. Eur J Cardiothorac Surg 2003; 23: 811-817.

7. Savonitto S, D'Urbano M, Caracciolo M, Barlocco F, Mariani G, Nichelatti M, Klugmann S, De Servi S. Urgent surgery in patients with a recently implanted coronary drug-eluting stent: a phase II study of 'bridging' antiplatelet therapy with tirofiban during temporary withdrawal of clopidogrel. $\mathrm{Br} J \mathrm{An}$ aesth 2010; 104: 285.

8. Rassi AN, Blackstone E, Militello MA, Theodos G, Cavender MA, Sun Z, Ellis SG, Cho L. Safety of "bridging" with eptifibatide for patients with coronary stents before cardiac and non-cardiac surgery. Am J Cardiol 2012; 110: 485-490.

9. Task Force on Myocardial Revascularization of the European Society of Cardiology (ESC) and the European Association for Cardio-Thoracic Surgery (EACTS); European Association for Percutaneous Cardiovascular Interventions (EAPCI), Wijns W, Kolh P, Danchin N, Di Mario C, Falk V, Folliguet T, Garg S, Huber K, James S, Knuuti J, Lopez-Sendon J, Marco J, Menicanti L, Ostojic M, Piepoli MF, Pirlet C, Pomar JL, Reifart N, Ribichini FL, Schalij MJ, Sergeant P, Serruys PW, Silber S, Sousa Uva M, Taggart D. Guidelines on myocardial revascularization. Eur Heart J 2010; 31: 2501-2555.

10. Dyszkiewicz W, Jemielity MM, Piwkowski CT, Perek B, Kasprzyk M. Simultaneous lung resection for cancer and myocardial revascularization without cardiopulmonary bypass (off-pump coronary artery bypass grafting). Ann Thorac Surg 2004; 77: 1023-1027.

11. Saxena P, Tam RK. Combined off-pump coronary artery bypass surgery and pulmonary resection. Ann Thorac Surg 2004; 78: 498-501.

12. Schoenmakers MC, van Boven WJ, van den Bosch J, van Swieten HA. Comparison of on-pump or off-pump coronary artery revascularization with lung resection. Ann Thorac Surg 2007; 84: 504-509.

13. Prokakis C, Koletsis E, Apostolakis E, Panagopoulos N, Charoulis N, Velissaris D, Filos K, Dougenis D. Combined heart surgery and lung tumor resection. Med Sci Monit 2008; 14: CS17-CS21.

14. Dyszkiewicz W, Jemielity M, Piwkowski C, Kasprzyk M, Perek B, Gasiorowski L, Kaczmarek E. The early and late results of combined off-pump coronary artery bypass grafting and pulmonary resection in patients with 
concomitant lung cancer and unstable coronary heart disease. Eur J Cardiothorac Surg 2008; 34: 531-535.

15. Cathenis K, Hamerlijnck R, Vermassen F, Van Nooten G, Muysoms F. Concomitant cardiac surgery and pulmonary resection. Acta Chir Belg 2009; 109: 306-311.

16. Hosoba S, Hanaoka J, Suzuki T, Takashima N, Kambara A, Matsubayashi K, Asai T. Early to midterm results of cardiac surgery with concomitant pulmonary resection. Ann Thorac Cardiovasc Surg 2012; 18: 8-11.

17. Albaladejo P, Marret E, Samama CM, Collet JP, Abhay K, Loutrel O, Charbonneau H, Jaber S, Thoret S, Bosson JL, Piriou V. Non-cardiac surgery in patients with coronary stents: the RECO study. Heart 2011; 97: 1566-1572.

18. Zhang R, Wiegmann B, Fischer S, Dickgreber NJ, Hagl C, Krüger M, Haverich A, Zardo P. Simultaneous cardiac and lung surgery for incidental solitary pulmonary nodule: learning from the past. Thorac Cardiovasc Surg 2012; 60: 150-155.

19. Schmid RA, Stammberger U, Hillinger S, Vogt PR, Amman FW, Russi EW, Weder W. Lung volume reduction surgery combined with cardiac interventions. Eur J Cardiothorac Surg 1999; 15: 585-591. 